\title{
How Can South Asia and Sub-Saharan Africa Gain From the Next WTO Round?
}

\author{
Kym Anderson \\ University of Adelaide \\ Shunli Yao \\ Chinese Academy of Sciences
}

\begin{abstract}
If South Asia and Sub-Saharan Africa are to become constructively engaged in the next attempt by World Trade Organization (WTO) members to liberalize trade multilaterally, they need to be convinced that there will be sufficient gains from trade reform to warrant the inevitable costs of negotiation and adjustment. This paper provides new estimates of the likely economic effects on their economies of further liberalizing world trade post-Uruguay Round. The results show that the developing countries of South Asia and Sub-Saharan Africa have much to gain from taking part in the next round. However, those gains will be far greater the more those countries are willing to embrace reform at home so as to enable their firms to take greatest advantage of the opportunities provided by the opening up of markets abroad.
\end{abstract}

- JEL Classifications: F13, F15, F17, O19

- Key words: Trade policy, WTO, Multilateral negotiations, Developing country gains

\footnotetext{
*Corresponding address: Professor, Kym Anderson, School of Economics and Executive Director, Centre for International Economic Studies, University of Adelaide, Adelaide, SA 5005, Australia. Phone +61 8 8303 4712, Fax +61 88223 1460, E-mail: kym.anderson@adelaide.edu.au Doctor Shunli Yao, Center for Chinese Agricultural Policy, Chinese Academy of Sciences, Beijing, China, Phone +86 106485 6532, Fax +86 106485 6533, E-mail: yaosl@igsnrr.ac.cn (C2003-Center for International Economics, Sejong Institution, All Rights Reserved.
} 


\section{Introduction}

At the Fourth Ministerial Meeting of the World Trade Organization (WTO) in Doha in November 2001, members agreed to launch the next comprehensive round of multilateral trade negotiations. The attempt to do so at the previous Ministerial in Seattle in late 1999 was aborted, not least because developing country members believed they had not benefited sufficiently from the preceding Uruguay Round. That belief still persists, and the developing countries of South Asia and Sub-Saharan Africa in particular remain sceptical that a new round of negotiations will benefit them - notwithstanding the substantial focus on their concerns in the Doha Ministerial Declaration (WTO 2001d). So sensitive are those concerns that the Declaration does not even refer to a new round, referring instead to a Doha Development Agenda.

If those numerous developing countries in South Asia and Sub-Saharan Africa are to become constructively engaged in this next attempt to liberalize trade multilaterally, they need to be convinced that there will be sufficient gains from trade reform to warrant the inevitable costs of negotiation and adjustment. To that end, this paper provides new estimates of the likely economic effects on their economies of further liberalizing world trade after Uruguay Round implementation is completed.

The paper begins by describing briefly the global economy-wide model known as GTAP, and then using it to provide two base projections of the world economy in 2005. By that time all Uruguay Round commitments are scheduled to be fully implemented, and most of the commitments made by China and Taiwan in their WTO accession negotiations will have been implemented. It is also the nominated date for concluding this next round of negotiations. The first base projection assumes that none of the Uruguay Round commitments are implemented, while the second assumes all are fully implemented and China and Taiwan have joined the WTO. The comparison between these two scenarios gives a sense of the size of the contribution to structural change that is generated by economic growth generally as compared with trade policy reform in particular.

Having established that second 2005 projection of the global economy, we then use the GTAP model to examine the consequences of removing the distortions to merchandise trade that will still be in place in 2005 post-Uruguay Round. We know from documentation at the WTO (2001a) and from recent GTAP modelling efforts that there will still be much to gain globally from further reform. The effects are 
considered first without and then with South Asia and Sub-Saharan Africa taking part. The purpose of the comparison between those two scenarios is to show the extent to which the economic benefits to those poor countries from the next WTO round depends on their own as distinct from other regions' liberalizations.

The final part of the paper discusses the limitations of the GTAP model in capturing all the gains from trade, and draws out implications for South Asia and Sub-Saharan African policy makers.

\section{The Global, Economy-Wide GTAP Model and Database}

To examine the potential effects of trade liberalizations on South Asian and Sub-Saharan African countries, use is made of the projections version of the GTAP (Global Trade Analysis Project) applied general equilibrium model based in Purdue University (Hertel 1997). The GTAP model is a standard, multi-region model that is currently in use by several hundred researchers in scores of countries on five continents. The Version 4 data base builds on contributions from many of these individuals, as well as the national and international agencies in the GTAP Consortium (McDougall, Elbehri and Truoung 1998). Perfect competition and constant returns to scale are assumed for all sectors of each economy in the version used here (but see qualifications in the final section of the paper).

The model utilizes a sophisticated representation of consumer demands that allows for differences in both the price and income responsiveness of demand in different regions depending upon both the level of development of the region and the particular consumption patterns observed in that region.

On the supply-side, differences in rates of factor accumulation within and between countries interact with different sectoral factor intensities to drive Rybczynski-type changes in the sectoral composition of output. The GTAP production system distinguishes sectors by their intensities in four primary factors of production: agricultural land, labour time, physical capital, and human capital. Thus in a region where physical capital is accumulating rapidly, relative to other factors, we can expect the capital intensive sectors to expand at the expense of labour-intensive sectors.

The GTAP framework is built on a complete set of economic accounts for 1995 for each of 45 economies/regions spanning the world (see McDougall et al. 1998). It incorporates an exhaustive description of inter-industry linkages between the 50 sectors in the model. In addition to differences in intermediate input intensities, 
import intensities are also permitted to vary across uses. Since much trade is in intermediate inputs, the distinction between sales to final consumers and sales to other firms can be quite important. Lowering the cost of imported goods to consumers is quite different from lowering the cost of intermediate inputs to domestic firms that may be competing with imports in the final product market.

As well, products are differentiated by place of production. The linkage between the different prices of a product is typically quite strong, but will depend on the degree of substitutability in consumption. In addition to matching up more effectively with reality, this approach has the advantage of permitting bilateral trade to be tracked, as opposed to simply reporting total exports net of imports.

Since it is cumbersome to conduct and present projections with the full 50sector, 45-region GTAP data base, the present results have been aggregated up to a level which highlights sectors and countries of interest for this particular study. Unfortunately, the regional aggregation in GTAP allows only the largest African and Asian economies to be shown separately. The model is solved with GEMPACK software, described in Harrison and Pearson (1996).

\section{Projecting the Post-Uruguay Round World Economy to 2005}

Version 4 of the GTAP model's data base is for 1995, the beginning of the Uruguay Round's implementation. Using estimates of the tariffs in place at the start and conclusion of Uruguay Round implementation (Table 1) and projections of growth in factor endowments, productivity and population to 2005 (based mainly on World Bank numbers -- see Table 2 in Anderson and Yao 2001), it is

Table 1. Import tariffs at the beginning (1995) and end (2005) of the Uruguay Round implementation period (\%)

\begin{tabular}{lcc|cc|cc}
\hline & $\begin{array}{c}\text { Agriculture and } \\
\text { food }\end{array}$ & \multicolumn{2}{c|}{$\begin{array}{c}\text { Other primary } \\
\text { products }\end{array}$} & \multicolumn{2}{c}{$\begin{array}{c}\text { Other } \\
\text { manufactures }\end{array}$} \\
\hline & Pre-UR & Post-UR & Pre-UR & Post-UR & Pre-UR & Post-UR \\
\hline All Advanced industrial countries & 16 & 13 & 0 & 0 & 2 & 2 \\
All developing countries & 16 & 14 & 6 & 4 & 16 & 14 \\
Northeast Asia & 28 & 26 & 3 & 3 & 4 & 4 \\
Southeast Asia & 24 & 21 & 3 & 2 & 20 & 19 \\
South Asia & 40 & 32 & 10 & 7 & 59 & 31 \\
Sub-Saharan Africa & 13 & 10 & 2 & 2 & 13 & 9 \\
\hline
\end{tabular}

Source: Francois and Strutt (1999). 
Table 2. Cumulative percentage change in sectoral output at 1995 prices resulting from global economic growth, 1995 to 2005

Assuming no Uruguay Round implementation or China WTO accession

\begin{tabular}{|c|c|c|c|c|c|c|c|c|c|}
\hline & ANZ & NEAsia & SEAsia & China & India & OthSAsia & $\begin{array}{l}\text { MidEast/ } \\
\text { NAfrica }\end{array}$ & SAfrica & $\begin{array}{c}\text { Other Sub- } \\
\text { Sahara }\end{array}$ \\
\hline Rice & 10 & 39 & 57 & 68 & 39 & 40 & 38 & 49 & 57 \\
\hline Wheat & 54 & 74 & 44 & 76 & 41 & 48 & 57 & 57 & 60 \\
\hline CerealGrain & 52 & 74 & 77 & 71 & 36 & 41 & 60 & 50 & 64 \\
\hline VegFruitNuts & 33 & 44 & 71 & 89 & 70 & 65 & 62 & 35 & 62 \\
\hline OilSeeds & 50 & 76 & 79 & 82 & 75 & 78 & 72 & 69 & 87 \\
\hline OthCrops & 44 & 68 & 80 & 75 & 75 & 77 & 78 & 60 & 111 \\
\hline PlantFibre & 65 & 91 & 101 & 78 & 75 & 82 & 79 & 90 & 138 \\
\hline Livestocks & 45 & 55 & 81 & 111 & 63 & 68 & 66 & 53 & 91 \\
\hline OthFoodProd & 34 & 22 & 44 & 88 & 58 & 64 & 45 & 38 & 48 \\
\hline MeatDairyPrd & 26 & 23 & 41 & 92 & 43 & 49 & 41 & 39 & 41 \\
\hline ForestryFish & 37 & 16 & 8 & 68 & 45 & 41 & 28 & 31 & 11 \\
\hline EnergMineral & 57 & 56 & 89 & 96 & 74 & 78 & 63 & 63 & 58 \\
\hline VegOilsFats & 27 & 31 & 44 & 90 & 55 & 66 & 41 & 35 & 51 \\
\hline TextileWap & 48 & 20 & 40 & 74 & 52 & 58 & 28 & 29 & 42 \\
\hline OtherManuf & 44 & 33 & 90 & 121 & 67 & 74 & 51 & 41 & 44 \\
\hline Services & 40 & 31 & 70 & 116 & 66 & 71 & 48 & 42 & 40 \\
\hline
\end{tabular}

Source: Authors' model results.

possible for the GTAP model to project the world's economies forward. Table 2 summarizes the results of such a base-case projection scenario for 2005 on output in developing and other economies, from which a number of points can be made.

First, non-trivial structural changes necessarily accompany different rates of expansion in (a) relative factor endowments and productivities and (b) incomes as economies grow. In general, the growth of agricultural and other primary product output is slower than that for manufactures and services in virtually all countries.

Second, outputs of all sectors tend to grow slower in slower-growing economies. This is a direct result of the home bias that is so prevalent in every nation's economy: foreign products, even of fairly homogeneous items such as cereals, are an imperfect substitute for the domestically produced item because of such things as nationalistic preferences and transport costs. Hence relatively rapidly growing China is projected to increase its output of agricultural goods over the decade to 2005 at a faster rate than South Asia (whose economies are projected to grow slower than China's). 
Table 3. Cumulative percentage change in sectoral output at 1995 prices resulting from global economic growth, 1995 to 2005

Assuming full Uruguay Round implementation and accession to WTO by China

\begin{tabular}{|c|c|c|c|c|c|c|c|c|c|}
\hline & ANZ & NEAsia & SEAsia & China & India & OthSAsia & $\begin{array}{l}\text { MidEast/ } \\
\text { NAfrica }\end{array}$ & SAfrica & $\begin{array}{c}\text { Other } \\
\text { SubSa- } \\
\text { hara }\end{array}$ \\
\hline$\overline{\text { Rice }}$ & 16 & 39 & 60 & 69 & 37 & 44 & 34 & 53 & 58 \\
\hline Wheat & 57 & 74 & 47 & 77 & 41 & 53 & 56 & 63 & 61 \\
\hline CerealGrain & 71 & 75 & 74 & 72 & 37 & 44 & 59 & 51 & 66 \\
\hline VegFruitNuts & 35 & 44 & 70 & 91 & 65 & 68 & 62 & 37 & 64 \\
\hline OilSeeds & 101 & 76 & 74 & 85 & 81 & 98 & 71 & 79 & 87 \\
\hline OthCrops & 42 & 69 & 79 & 77 & 78 & 94 & 78 & 63 & 117 \\
\hline PlantFibre & 59 & 94 & 106 & 77 & 81 & 101 & 79 & 82 & 150 \\
\hline Livestocks & 53 & 53 & 76 & 111 & 64 & 74 & 65 & 68 & 94 \\
\hline OthFoodProd & 46 & 22 & 41 & 87 & 49 & 66 & 44 & 71 & 50 \\
\hline MeatDairyPrd & 41 & 21 & 31 & 92 & 56 & 53 & 41 & 57 & 44 \\
\hline ForestryFish & 38 & 16 & 7 & 69 & 45 & 40 & 29 & 31 & 14 \\
\hline EnergMineral & 57 & 57 & 89 & 101 & 70 & 82 & 64 & 60 & 62 \\
\hline VegOilsFats & 300 & 31 & 32 & 92 & 54 & 37 & 36 & 88 & 45 \\
\hline TextileWap & 26 & 16 & 159 & 73 & 112 & 177 & 23 & 19 & 31 \\
\hline OtherManuf & 41 & 34 & 87 & 135 & 60 & 116 & 52 & 44 & 45 \\
\hline Services & 40 & 31 & 70 & 119 & 67 & 83 & 48 & 42 & 42 \\
\hline
\end{tabular}

Source: Authors' model results.

Third, the proportional changes over the decade are very similar in the two scenarios (compare Tables 2(a) and 2(b)). This is a crucial point that is often not appreciated. The point is that as major as the Uruguay Round is, the impact of its decade-long implementation on the structure of the world's economies is small relative to the impact of normal market forces that accompany economic growth over such a longish period.

Fourth, within South Asia and Sub-Saharan Africa, perhaps the most significant structural change difference between the two scenarios has to do with textiles and clothing. The densely populated countries in South Asia are projected to have significantly bigger textile and clothing (and slightly bigger service) sectors because of the Uruguay Round reforms, but in India's case a smaller share of output from other manufactures. (This scenario assumes, however, that there is full implementation of the Uruguay Round's Agreement on Textiles and Clothing, without any offsetting safeguards measures being implemented at the end of the 
reform period in late 2004; and that reform of China's quota-restricted trade in these products is not complete until 2008 rather than 2005.) In more agrarian and less densely populated Sub-Saharan Africa, by contrast, the textile and clothing industries would grow somewhat slower following Uruguay Round implementation as that region instead exploits new market opportunities for its more-competitive primary industries.

Fifth, notice that the service sector's expansion is shown to be not very different under the two scenarios in proportional terms (although in dollar terms that huge sector would be significantly bigger under freer trade). This is because we assume, like most of our predecessor modellers, that the General Agreement on Trade in Services (GATS) will deliver no significant reforms by 2004.

Changes in consumption also accompany economic growth and policy reforms, and it is the difference between them and the production changes that determine the changes in sectoral trade balances. The latter can be summarized in terms of the self sufficiency ratio (the ratio of production over consumption), where it should be kept in mind that the sum of the sectoral trade balance changes is set exogenously by the modellers at zero (that is, no running up or running down the aggregate balance of trade over time). The results show a remarkable degree of stability as between the two projection scenarios for developing countries. The implementation of the Uruguay Round is not projected to cause major changes in agricultural self-sufficiency, for example. In fact the only significant differences between the scenarios are in manufactures: South Asia will specialize more in textiles and clothing and less in other manufactures because of the Uruguay Round, while Sub-Saharan Africa will specialize more in primary products and less in industrial goods (see Table 4 of Anderson and Yao 2001).

\section{Effects of Removing Remaining Distortions to Goods Trade in 2005}

Having established the post-Uruguay Round base-case projection scenario for 2005, we examine how different the world would look then if the remaining import tariffs on all goods, and all agricultural producer and export subsidies, were to be removed. This thought experiment is done in two stages: first, with all except South Asian and Sub-Saharan African distortions removed, and then with those developing countries' policies abolished as well.

If all regions (other than South Asia and Sub-Sahara) were to remove their trade 
Table 4. Percentage difference in sectoral output when all merchandise trade distortions remaining post-UruguayRound are removed, 2005 In all regions except South Asia and Sub-Saharan Africa

\begin{tabular}{|c|c|c|c|c|c|c|c|c|c|}
\hline & ANZ & NEAsia & SEAsia & China & India & OthSAsia & $\begin{array}{c}\text { MidEast/ } \\
\text { Nafrica }\end{array}$ & SAfrica & $\begin{array}{c}\text { Other } \\
\text { Sub } \\
\text {-Sahara }\end{array}$ \\
\hline Rice & 19 & -9 & -12 & 3 & 12 & 9 & 6 & 6 & 1 \\
\hline Wheat & 103 & -66 & -16 & 15 & 6 & 6 & 11 & 18 & 2 \\
\hline CerealGrain & 10 & -52 & -12 & 14 & 1 & 1 & 2 & 114 & 85 \\
\hline VegFruitNuts & -7 & 1 & 1 & 1 & 1 & 1 & -1 & 1 & 0 \\
\hline OilSeeds & -5 & -15 & 14 & 45 & -1 & 2 & 0 & 2 & 3 \\
\hline OthCrops & 84 & -8 & 5 & -4 & -2 & 1 & 3 & 43 & -8 \\
\hline PlantFibre & -21 & 32 & 9 & 35 & -2 & 0 & 81 & -12 & 11 \\
\hline Livestocks & 28 & -13 & -5 & 1 & 0 & 1 & 12 & 28 & 15 \\
\hline OthFoodProd & -16 & 15 & 4 & 2 & -2 & 29 & -1 & 28 & 2 \\
\hline MeatDairyPrd & 67 & -6 & -23 & 55 & 1 & 3 & 3 & 38 & 14 \\
\hline ForestryFish & -1 & 0 & 2 & 1 & 0 & 1 & 1 & 2 & 0 \\
\hline EnergMineral & -1 & 0 & 2 & 8 & 1 & 2 & 2 & -2 & 0 \\
\hline VegOilsFats & -21 & 112 & 43 & -14 & -4 & -5 & -4 & 0 & 0 \\
\hline TextileWap & -17 & 35 & -24 & 70 & -10 & -16 & 14 & -8 & -2 \\
\hline OtherManuf & -1 & 4 & 35 & 6 & 3 & 11 & 7 & -7 & 0 \\
\hline Services & 1 & 1 & -2 & 2 & 0 & 0 & 2 & 0 & 0 \\
\hline
\end{tabular}

Source: Authors' model results.

distortions remaining after the end of 2004 (when all Uruguay Round commitments are to have been implemented), the world economy would structurally adjust to allow each region to exploit even more its comparative advantages. For example, Table 3(a) shows Australia and New Zealand would expand their temperate crop and livestock output as the agricultural protectionist countries of East Asia contracted theirs. It is the comparison between Tables 3(a) and 3(b) for South Asia and Sub-Saharan Africa that are of particular interest in this paper, however.

The first point to note is that South Asia and Sub-Saharan Africa would have to undertake some structural changes within and between key sectors even if they chose not to join in such a trade reform (Table 3(a)). In particular, agriculture would expand at the expense of labour-intensive manufacturing in those developing countries.

Second, South Asia would expand its agricultural output more if it also undertakes reforms itself than if it stands aside from reform. Its textile/clothing 
Table 5. Percentage difference in sectoral output when all merchandise trade distortions remaining post-UruguayRound are removed, 2005

In all regions including South Asia and Sub-Saharan Africa

\begin{tabular}{|c|c|c|c|c|c|c|c|c|c|}
\hline & ANZ & NEAsia & SEAsia & China & India & OthSAsia & $\begin{array}{l}\text { MidEast/ } \\
\text { NAfrica }\end{array}$ & SAfrica & $\begin{array}{c}\text { Other } \\
\text { SubSa- } \\
\text { hara }\end{array}$ \\
\hline Rice & 5 & -9 & -12 & 2 & 19 & 18 & -1 & 4 & -1 \\
\hline Wheat & 101 & -66 & -15 & 14 & 15 & 7 & 10 & -3 & -6 \\
\hline CerealGrain & 10 & -51 & -11 & 14 & 1 & 2 & 2 & 171 & 90 \\
\hline VegFruitNuts & -7 & 1 & 2 & 1 & 0 & -3 & -1 & 1 & 9 \\
\hline OilSeeds & -5 & -14 & 22 & 45 & 0 & 7 & -1 & -5 & -1 \\
\hline OthCrops & 82 & -6 & -1 & -2 & -2 & -4 & 1 & 61 & 9 \\
\hline PlantFibre & -19 & 30 & 12 & 21 & -2 & -1 & 85 & -10 & -1 \\
\hline Livestocks & 29 & -13 & -5 & 3 & 0 & 6 & 10 & -6 & 54 \\
\hline OthFoodProd & -17 & 16 & 3 & 1 & 1 & 38 & 0 & 22 & 3 \\
\hline MeatDairyPrd & 70 & -5 & -23 & 54 & 2 & 8 & 3 & -6 & 0 \\
\hline ForestryFish & -2 & 0 & 2 & 1 & 0 & 3 & 2 & 7 & 4 \\
\hline EnergMineral & -1 & 1 & 0 & 4 & 6 & 3 & 2 & 29 & 7 \\
\hline VegOilsFats & -20 & 106 & 67 & -13 & -15 & -17 & -4 & 0 & 2 \\
\hline TextileWap & -22 & 36 & -2 & 56 & 5 & 29 & 8 & 1 & -13 \\
\hline OtherManuf & 0 & 2 & 35 & -2 & 19 & 60 & 9 & -8 & -5 \\
\hline Services & 1 & 1 & -2 & 1 & 2 & 4 & 2 & 1 & 0 \\
\hline
\end{tabular}

Source: Authors' model results.

output, by contrast, would shrink a little if it stands aside from reform but would expand if it joins in. The latter expansion would not be at the expense of other manufactured output, though. On the contrary, a comparison between Tables 3(a) and 3(b) reveals that industrial and service sector output generally also is greater in that region when it participates in reform. That is, the removal of South Asia's own distortionary policies expands all sectors of its economies, even if the manufacturing sector is the one to grow fastest.

And third, the output differences between the two reform scenarios for SubSaharan Africa suggest this region too would enjoy faster growth in output if it freed up its own trade. For South Africa, the biggest boost would be in mineral and energy at the expense of livestock products while for the rest of Sub-Saharan Africa primary products expand slightly at the expense of manufactures.

The trade balance for the different product groups is affected by the above production effects plus changes in consumption following relative price and income changes. The net effects are seen by comparing Tables 4(a) and 4(b). The 
Table 6. Changes in sectoral trade balances when all merchandise trade distortions remaining post-UruguayRound are removed, 2005

Reform in all regions except South Asia and Sub-Saharan Africa

\begin{tabular}{|c|c|c|c|c|c|c|c|c|c|}
\hline & ANZ & NEAsia & SEAsia & China & India & $\begin{array}{l}\text { OthSA- } \\
\text { sia }\end{array}$ & $\begin{array}{l}\text { MidEast/ } \\
\text { NAfrica }\end{array}$ & SAfrica & $\begin{array}{c}\text { Other } \\
\text { SubSa- } \\
\text { hara }\end{array}$ \\
\hline Rice & 74 & -413 & $-2,517$ & 321 & 1,897 & 397 & -110 & -54 & 28 \\
\hline Wheat & 4,628 & $-14,709$ & -921 & 2,284 & 671 & 48 & 2,040 & -50 & 44 \\
\hline CerealGrain & 137 & $-44,341$ & $-3,150$ & 1,517 & 50 & 1 & 111 & 1,016 & 1,815 \\
\hline VegFruitNuts & -75 & -348 & -281 & 285 & 67 & -17 & -103 & -114 & -8 \\
\hline OilSeeds & -40 & -579 & -213 & 3,680 & 119 & 39 & -51 & -79 & 48 \\
\hline OthCrops & 4,306 & $-2,751$ & -233 & $-1,265$ & 28 & -108 & -150 & 2,427 & $-2,068$ \\
\hline PlantFibre & -164 & $-1,745$ & 10 & $-2,815$ & 30 & -70 & 3,720 & -106 & 589 \\
\hline Livestocks & -100 & -281 & 70 & 51 & 6 & 4 & 1,316 & 21 & 365 \\
\hline OthFoodProd & $-6,734$ & 23,172 & 1,291 & $-10,412$ & -494 & 3,232 & $-3,025$ & 5,062 & 339 \\
\hline MeatDairyPrd & 16,749 & $-30,011$ & $-3,727$ & 11,242 & 153 & 130 & -2 & 2,954 & 569 \\
\hline ForestryFish & -60 & -734 & $-1,583$ & -215 & 0 & -25 & -28 & -4 & -54 \\
\hline EnergMineral & -365 & $-7,505$ & $-8,506$ & 6,491 & 185 & -297 & -853 & -436 & -198 \\
\hline VegOilsFats & -702 & 1,921 & 3,988 & $-2,412$ & -186 & -70 & -583 & -145 & -22 \\
\hline TextileWap & $-1,844$ & 63,044 & $-19,748$ & 39,013 & $-7,159$ & $-6,315$ & -227 & -498 & -143 \\
\hline OtherManuf & $-13,019$ & 45,176 & 49,005 & $-40,500$ & 4,552 & 3,484 & $-15,432$ & $-8,066$ & -469 \\
\hline Services & $-2,792$ & $-29,896$ & $-13,483$ & $-7,266$ & 80 & -433 & 13,377 & $-1,927$ & -836 \\
\hline
\end{tabular}

Source: Authors' model results.

key point to draw from them is that net food imports are less for South Asia and Sub-Saharan Africa following the removal of remaining trade barriers in 2005, and more so when those developing countries participate in the reform.

Table 5 summarizes the estimated effects on economic welfare without and with South Asia and Sub-Saharan Africa participating in the removal of remaining distortions post-Uruguay Round. The global welfare gain is well over US\$200 billion per year, and of course more if all countries participate. South Asia's gains are hugely greater if it participates than if it does not: $\$ 14$ billion per year compared with just one-tenth of that amount if it does not -- despite the fact that South Asia's own liberalization would turn the international terms of trade against itself. The reason is that the region's resources are used so much more efficiently when its own distortionary policy interventions are removed.

Sub-Saharan Africa's gain when it reforms is less than 40 per cent of South Asia's gain. This partly reflects the fact that the South Asian economies in aggregate are nearly twice as large as the whole of Sub-Saharan Africa. When 
Table 7. Changes in sectoral trade balances when all merchandise trade distortions remaining post-UruguayRound are removed, 2005

Reform in all regions including South Asia and Sub-Saharan Africa

\begin{tabular}{|c|c|c|c|c|c|c|c|c|c|}
\hline & ANZ & NEAsia & SEAsia & China & India & $\begin{array}{c}\text { OthSA- } \\
\text { sia }\end{array}$ & $\begin{array}{c}\text { Mid- } \\
\text { East/ } \\
\text { NAfrica }\end{array}$ & SAfrica & $\begin{array}{c}\text { Other } \\
\text { SubSa- } \\
\text { hara }\end{array}$ \\
\hline Rice & 32 & -438 & $-2,853$ & 128 & 2,565 & 689 & -139 & -82 & -54 \\
\hline Wheat & 4,535 & $-14,709$ & $-1,023$ & 2,297 & 1,736 & 163 & 1,830 & -152 & -252 \\
\hline CerealGrain & 134 & $-44,362$ & $-3,333$ & 1,500 & 67 & 0 & 78 & 1,681 & 1,911 \\
\hline VegFruitNuts & -73 & -354 & -151 & 314 & -118 & -590 & -349 & -66 & 881 \\
\hline OilSeeds & -39 & -591 & -299 & 3,726 & 224 & -175 & -64 & -62 & 68 \\
\hline OthCrops & 4,199 & $-2,721$ & -751 & $-1,323$ & -647 & $-2,001$ & -309 & 3,609 & 1,704 \\
\hline PlantFibre & -157 & $-1,688$ & 43 & $-2,619$ & -244 & -782 & 3,968 & -73 & 158 \\
\hline Livestocks & -151 & -277 & 68 & 40 & -3 & 7 & 1,045 & 73 & 1,146 \\
\hline OthFoodProd & $-6,875$ & 22,670 & 1,251 & $-10,342$ & 195 & 3,530 & $-2,320$ & 4,976 & 230 \\
\hline MeatDairyPrd & 17,456 & $-30,056$ & $-3,625$ & 11,336 & 458 & 36 & -49 & -480 & -239 \\
\hline ForestryFish & -69 & -707 & $-1,651$ & -217 & -234 & -148 & -71 & 29 & 270 \\
\hline EnergMineral & -344 & $-7,688$ & $-8,743$ & 6,339 & -410 & $-3,381$ & $-3,168$ & 6,760 & 4,442 \\
\hline VegOilsFats & -724 & 1,955 & 6,210 & $-2,398$ & $-1,292$ & -585 & -616 & -125 & -46 \\
\hline TextileWap & $-1,917$ & 59,749 & $-20,410$ & 34,541 & 629 & 3,706 & $-2,227$ & -605 & $-1,490$ \\
\hline OtherManuf & $-13,258$ & 48,765 & 49,172 & $-36,399$ & $-5,068$ & 1,698 & $-9,386-$ & $-14,086$ & $-8,054$ \\
\hline Services & $-2,749$ & $-29,548$ & $-13,904$ & $-6,926$ & 2,142 & $-2,168$ & 11,778 & $-1,398$ & -676 \\
\hline
\end{tabular}

Source: Authors' model results.

South Africa is disaggregated from Other Sub-Saharan Africa, however, then as shown in Table 5 it appears Other Sub-Saharan Africa in aggregate does not gain any more from participating in than from standing aside from further trade liberalization. The reason is clear from Table 5: the very considerable gains from more efficient resource use are offset by an adverse change in its terms of trade when all of those countries expand their primary product exports simultaneously.

Does that mean the economy of each Sub-Saharan African country would be better off if its government did not participating in the next WTO round? Certainly not. On the contrary, their economy's welfare would be even worse if their government did not participate, for several reasons. One is that it would forego the economic efficiency gains from reforming its own policies while still suffering the terms of trade loss from others' reforms (since any one of those countries is too small for its own policy choice to alter the terms of trade significantly).1 Second, it would forego the opportunity to seek through the negotiations greater market access for its particular exports to other countries. And third, there is the promise 
Table 8. Economic welfare effects of all merchandise trade distortions remaining post-Uruguay Round being removed (a) without and (b) with South Asia and Sub-

Saharan Africa participating, 2005(US\$ million per year in 1995 dollars)

(a) Without South Asia/SS Africa

(b) With South Asia/SS Africa

\begin{tabular}{lrrrrrr}
\hline & $\begin{array}{c}\text { Resource use } \\
\text { efficiency }\end{array}$ & $\begin{array}{c}\text { Terms of } \\
\text { trade }\end{array}$ & TOTAL & $\begin{array}{c}\text { Resource use } \\
\text { efficiency }\end{array}$ & $\begin{array}{c}\text { Terms of } \\
\text { trade }\end{array}$ & TOTAL \\
\hline ANZ & 975 & 5,645 & 6,451 & 1,016 & 5,852 & 6,702 \\
NEAsia & 86,290 & 10,110 & 93,265 & 86,635 & 11,497 & 95,172 \\
SEAsia & 18,402 & $-8,505$ & 9,359 & 18,710 & $-7,233$ & 10,934 \\
China & 19,144 & $-10,634$ & 8,734 & 18,619 & $-9,913$ & 9,053 \\
India & 570 & 315 & 806 & 12,596 & $-4,808$ & 7,414 \\
OtherSAsia & 353 & 342 & 578 & 10,452 & $-3,128$ & 6,245 \\
NthAmerica & 7,422 & 10,099 & 16,852 & 8,028 & 13,150 & 20,476 \\
Mexico & 2,174 & $-1,799$ & 897 & 2,240 & $-1,927$ & 867 \\
SouthernCone & 15,956 & $-3,089$ & 12,042 & 15,767 & $-3,111$ & 11,816 \\
OtherLatinAm & 1,969 & 3,507 & 5,341 & 2,009 & 3,690 & 5,562 \\
WEurope & 55,227 & $-8,518$ & 47,359 & 55,712 & $-6,401$ & 50,130 \\
EEFSU & 2,848 & 5,718 & 8,491 & 2,935 & 5,985 & 8,860 \\
MidEastNAfr & 8,956 & $-5,202$ & 3,146 & 9,642 & $-3,426$ & 5,565 \\
SthAfrica & -425 & 2,159 & 1,726 & 3,515 & 1,196 & 4,589 \\
OthSubSahara & -147 & 728 & 577 & 1,198 & -715 & 520 \\
Rest of World & 6,934 & $-1,271$ & 4,726 & 6,976 & $-1,257$ & 4,748 \\
TOTAL & 226,648 & -394 & 220,348 & 256,052 & -550 & 248,653 \\
\hline
\end{tabular}

Source: Authors' model results.

in this next round that any participating poor economies that lose from taking part in the multilateral liberalization could secure much more compensation than in previous rounds, in the form of technical assistance and funds for trade policy capacity building (WTO 2001b).

It is thus in the national economic interest of such countries to be pressured from abroad to commit to such reform, painful though that may be politically for its government. The political pain tends to be less, and the prospect for a net economic gain greater, the more sectors the country involves in the reform. The economic gain is prospectively greater the more sectors it involves because a wider net reduces the possibility that reform is confined to a subset of sectors that are not the most distorted. (When so confined, resources might move from the reformed sector to even more inefficient uses, thereby reducing rather than improving the efficiency of national resource use. 2)

Notice that other parts of the world gain a little more when all regions 
participate, in their case because of improved terms of trade when South Asia and Sub-Saharan Africa take part.

\section{Qualifications and Policy Implications}

Of course net national economic welfare is not the only criterion that drives governments to act as they do. Indeed until recently, it may not have been even a major one. However, it is steadily becoming more dominant, for at least three reasons. One is the rapid globalization of the world that technological and economic policy changes have stimulated over the past decade or so, a major effect of which is that economies will be penalized ever-more rapidly and severely through capital flight for bad economic governance.

Another reason is the broader mandate of the WTO, which makes it easier now than before the Uruguay Round for developing countries to engage profitably in cross-sectoral exchange of market access commitments, including in services trade.

A third reason is that it is becoming better understood that there are three other important source of gains from trade reform that are not captured in the above results, namely, gains from reform to trade in services, gains from increasing competition and economies of scale, and dynamic gains.

While measuring distortions to services trade and mark-ups by imperfectly competitive firms is fraught with difficulty, initial attempts are beginning to bear fruit. A new study by Francois (2001) includes one set of estimates of the tariff equivalent of those distortions in a version of the GTAP model that also incorporates imperfect competition and scale economies. Specifically, that study assumes monopolistic competition exists in the non-primary sectors involving economies of scale that are internal to each firm. These modifications amplify the estimated gains from trade considerably. For example, that study finds that if applied tariff rates for both goods and services were to be cut in half, the global gains would be US $\$ 385$ billion, of which 51 per cent would be due to services reform. The 49 per cent due to halving tariffs on goods trade ( $\$ 192$ billion) in the Francois study compares with the estimate reported in Table 5 (where no imperfect competition is assumed) of $\$ 249$ billion from totally removing all tariffs on merchandise trade. The distribution of those gains to the developing countries focused on in our study is very similar to that reported in Table 5: about 3 per cent is attributed to India and 2 per cent to Sub-Saharan Africa.

The key point to draw from this comparison is that the gains from trade reported 
in the previous section should be interpreted as lower-bound estimates for at least two reasons: because they apply only to goods trade, leaving aside the important distortions prevalent in services markets; and because they are based on the assumption that there are no economies of scale and that perfect competition prevails in all sectors.

Both aspects of this point are especially important for Sub-Saharan Africa. With respect to policies at home they are important partly because that region has among the highest barriers to services trade (Francois 2001, Table C.2), and partly because the region's national economies are small and hence those services trade barriers translate into a high degree of monopolistic activity and diseconomies of small scale.

With respect to policies abroad, this point is perhaps even more important for Sub-Saharan Africa, especially as it applies to ocean shipping. Two-thirds of SubSaharan African exports are primary products. Most of them are being shipped in bulky unprocessed or semi-processed form. The region's export earnings are thus affected significantly by the cost of ocean shipping services. That service sector is characterised by a high degree of oligopolistic activity on the part of ship owners, virtually all of whom are developed country firms. While ever that service sector remains restrictive, the benefits of freer trade will be captured in part by the cartel of shipowners who can charge a higher mark-up above their marginal costs as import tariffs on goods are lowered.

To illustrate this last point, a recent empirical study was undertaken by Francois and Wooten (2000). They estimate that, depending on the degree of collusion, shippers could absorb for themselves, in the form of higher mark-ups, up to half the gains that exporters would otherwise enjoy from goods trade liberalization if only shipping was a competitive service activity. The clear conclusion to draw from the Francois/Wooten study is that liberalizing trade in maritime services under GATS is likely to boost substantially the gains from merchandise trade reform and especially reform of bulky commodities such as agricultural products.

None of the studies reported above draw on a truly dynamic economic model. They measure well the effects of producers reallocating their resources and consumers adjusting their purchases when relative product prices change with trade reform, but they do not measure the impact of such reform on investment behaviour. Yet we know from experience that when markets are freed up, investors divert their funds towards expanding the now-more-profitable activities and away from the now-less-profitable ones. They are also willing to invest more in 
aggregate, because of the reduced uncertainty associated with binding the reforms in WTO schedules. That boost to investment applies even more following the reductions in barriers to foreign investment and hence international technology transfers of the past two decades. Thus economic growth is boosted by that diversion and expansion of investment funds, over and above the boost in output from reallocating existing resource endowments.

This additional effect is omitted from most empirical modelling efforts for two reasons: partly because it takes much longer for analysts to build and to run dynamic models than comparative static ones, and partly because the extent to which investors respond to changing incentives is less well understood and hence cannot be included with as much certainty as the other behavioural characteristics that are common to both comparative static and dynamic models. Keeping that in mind, it is nonetheless instructive to note the results of a recent study that examined the range of outcomes generated as the responsiveness of productivity to openness is varied.

The World Bank (2001, Ch. 6) conducted a study very similar to the one reported in Section 3 above, and obtained very similar results when its version of the GTAP model was in comparative static mode (a global welfare gain from complete liberalization of merchandise trade of $\$ 312$ billion per year by 2015 , compared with the present study's estimate of $\$ 249$ billion as early as 2005 when the world economy would be somewhat smaller). When their same model was switched into dynamic mode, however, that global gain increased two- to three-fold over reasonable ranges of productivity responsiveness parameters. This adds further weight to the claim that the earlier welfare results should be considered as very much lower-bound estimates of the gains from trade liberalization.

In short, the developing countries of South Asia and Sub-Saharan Africa have much to gain from taking part in the next round of WTO negotiations to liberalize trade, and more so the more they are willing to embrace reform at home so as to enable their firms to take greatest advantage of the opportunities provided by the opening up of markets abroad.

Received May 2002, Accepted 18 June 2002

\section{References}

Anderson, K., B. Dimaranan, T. Hertel and W. Martin (1997), "Economic Growth and 
Policy Reforms in the APEC Region: Trade and Welfare Implications by 2005", Asia-Pacific Economic Review 3(1), 1-18, April.

Anderson, K. and A. Strutt (1999), "Impact of East Asia's Growth Interruption and Policy Responses: The Case of Indonesia”, Asian Economic Journal 13(2), 205-18, June.

Anderson, K. and S. Yao (2001), "How Can South Asia and Sub-Saharan Africa Gain From the Next WTO Round?" CIES Discussion Paper No. 0145, University of Adelaide, November.

Francois, J, (2001), The Next WTO Round: North-South Stakes in New Market Access Negotiations, Adelaide: Centre for International Economic Studies and Rotterdam: Tinbergen Institute.

Francois, J. and A. Strutt (1999), "Post-Uruguay Round Tariff Vectors for GTAP Version 4", Erasmus University manuscript, Rotterdam.

Francois, J.F. and I. Wooten (2000), "Trade in International Transport Services: The Role of Competition", CEPR Discussion Paper No. 2377, London: Centre for Economic Policy Research, February.

Harrison, W. J. and K. R. Pearson (1996), "Computing Solutions for Large General Equilibrium Models Using GEMPACK”, Computational Economics 9, 83-172.

Hertel, T.W. (ed.) 1997. Global Trade Analysis: Modeling and Applications, Cambridge and New York: Cambridge University Press.

Martin, W. and L.A. Winters (eds.) (1996), The Uruguay Round and the Developing Countries, Cambridge and New York: Cambridge University Press.

McDougall, R.A., A. Elbehri and T.P. Truong (1998) (eds.) Global Trade, Assistance, and Protection: The GTAP 4 Data Base. Center for Global Trade Analysis, Purdue University, West Lafayette.

World Bank (2001), Global Economic Prospects and the Developing Countries 2002: Making World Trade for the World's Poor, Washington, D.C.: The World Bank.

WTO (2001a), Market Access: Unfinished Business: Post-Uruguay Round Inventory and Issues, Special Study No. 6, Geneva: World Trade Organization.

WTO (2001b), Doha WTO Ministerial 2001: Ministerial Declaration, WT/MIN(01)/ DEC/1, Geneva: World Trade Organization, 14, November. 